\title{
Partial Substitution of Cement Using Fly Ash and Carbite Waste in Normal Concrete Making
}

\author{
Darma Prabudi ${ }^{1, *}$ Kosim $^{1}$ Zainuddin $^{1}$ Raja Marpaung ${ }^{1}$
}

\author{
${ }^{1}$ Civil Engineering Department, Politeknik Negeri Sriwijaya \\ ${ }^{*}$ Corresponding author. Email: darma_prabudi@yahoo.com
}

\begin{abstract}
Concrete is a mixture consisting of crushed stone or coral, sand, cement, water, and additives if needed. While the concrete to be designed is concrete made from a mixture of cement plus (fly ash + carbide waste), crushed stone, sand, and water. Therefore, it is necessary to make a mixture between cement with fly ash and carbide waste, the percentage of fly ash use is $75 \%$ and carbide waste is $25 \%$. In this study, we will use a variation (fly ash + carbide waste) and cement is 0\% FA + LK: 100\% PC; 20\% FA + LK: 80\% PC; 40\% FA + LK: 60\% PC; 60\% FA + LK: 40\% PC; $80 \%$ FA + LK: $20 \% \mathrm{PC}$. The testing results for concrete compressive strength without fly ash and carbide waste obtained at the age of 3, 7, 14 and 28 days, the value of concrete compressive strength are $132.88 \mathrm{~kg} / \mathrm{cm} 2,243.56 \mathrm{~kg} / \mathrm{cm} 2$, $259.93 \mathrm{~kg} / \mathrm{cm} 2,285,19 \mathrm{~kg} / \mathrm{cm} 2$, and fulfills the concrete compressive strength $275 \mathrm{~kg} / \mathrm{cm} 2$ at the age of 28 days. The concrete compressive strength with $20 \%$ (FA + LK) and $80 \%$ PC material at the ages of 3, 7, 14 and 28 days, the compressive strength at 3 days is $127.29 \mathrm{~kg} / \mathrm{cm} 2,7$ days old is $190,37 \mathrm{~kg} / \mathrm{cm} 2,14$ days old was $246.22 \mathrm{~kg} / \mathrm{cm} 2$ and 28 days old was $279.26 \mathrm{~kg} / \mathrm{cm} 2$. The testing results of concrete compressive strength above have met the planned concrete compressive strength, which is $275 \mathrm{~kg} / \mathrm{cm} 2$ at the age of 28 days. Meanwhile $40 \%$ FA + LK: $60 \%$ PC; 60\% FA + LK: 40\% PC; 80\% FA + LK: 20\% PC, does not meet the quality requirements of K-275 concrete. Concrete mixture using 20\% (FA + LK) and 80\% PC is the best concrete mixture, and the compressive strength of concrete is $279.26 \mathrm{~kg} / \mathrm{cm} 2$. The more the percentage use of fly ash and carbide waste into the concrete mixture, the compressive strength of the concrete will decrease.
\end{abstract}

Keywords: Fly Ash, Carbide Waste, Concrete Age, Concrete Compressive Strength

\section{INTRODUCTION}

Concrete is a mixture of crushed stone, sand, cement, water, and additives (if needed). Ordinary concrete has a low tensile strength compared to its compressive strength so that for structural implementation it is necessary to install steel reinforcement to withstand tensile forces, such concrete is called reinforced concrete. Another type of concrete is called pre-compressed concrete, it is first given a compressive force to the concrete to compensate for the working tensile force. The concrete to be designed is concrete made from a mixture of cement plus (fly ash + carbide waste), crushed stone, sand, and water. Fly ash (fly ash) is a useful additive to improve the properties of concrete. Fly ash can be classified as a pozzolanic material, the name pozzolan is derived from the name of a city in Italy (Pozzuoli) which produces a natural adhesive (Alfian H. U., et al., 2014).
While this carbide waste has physical properties that resemble calcium hydroxide in that the largest chemical compound is $\mathrm{Ca}(\mathrm{OH}) 2$, its binding capacity to water is quite high, has a grainy texture, has a distinctive odor, and the grain diameter is relatively larger. compared to clay grains. The addition of carbide waste is an effort to increase the calcium element required in the occurrence of a pozzolanic reaction when mixed with $\mathrm{SiO} 2$ in the carbide waste. (Utomo, 2010).

With this cement material the longer it will be getting thinner. For this reason, it is necessary to make concrete with a mixture of cement with fly ash and carbide waste, the percentage of use of fly ash is $75 \%$ and carbide waste is $25 \%$. Problems: In this study, to determine the effect of using fly ash and carbide waste in the manufacture of concrete, the composition of the concrete mixture was made by varying the volume ratio between waste and cement: $0 \% \mathrm{FA}+\mathrm{LK}: 100 \% \mathrm{PC}$; $20 \%$ FA + LK: $80 \%$ PC; $40 \%$ FA + LK: $60 \%$ PC; $80 \%$ 
FA + LK: 20\% PC. The goal is to calculate the strength of the concrete produced with a ratio of $0 \% \mathrm{FA}+\mathrm{LK}$ : 100\% PC; $20 \%$ FA + LK: $80 \%$ PC; $40 \%$ FA + LK: $60 \%$ PC; $80 \%$ FA + LK: $20 \%$ PC. Calculating the ratio between (fly ash + waste carbide) and cement in the manufacture of concrete. Obtaining the strength of concrete reviewed at the age of $3,7,14$ and 28 days. Expected benefits: can determine alternative materials for waste materials in normal concrete production, can determine the age of concrete that produces the expected compressive strength, can reduce the use of cement in concrete production.

\section{LITERATURE REVIEW}

\subsection{Concrete properties}

\section{Properties of fresh concrete}

"Concrete can be defined as a mixture of water, aggregate and cement". There are several things that can be affected by the nature of fresh concrete, namely:

\section{- Environmental conditions}

Environmental factors that can worsen the working properties of concrete are temperature, humidity, and wind speed. Temperature influences the amount of water used, because rising temperatures speed up the amount of water used for heat hydration and losses due to evaporation. Meanwhile, humidity and wind speed affect the speed of water evaporation.

- Time

Deteriorating working properties related to time are a direct result of loss of free water through curing, aggregate absorption, and initial hydration of cement.

\section{- Stability}

Besides having to be easy to work with, the composition of the fresh concrete mixture must be stable evenly distributed during stirring until completion of compaction before the concrete binds. The difference in grain size and density of the concrete mix ingredients will result in a tendency for these materials to separate or be difficult to mix.

\section{The properties of hardened concrete}

The fresh properties are important only a few hours after the mixing is complete, while the properties of the hardened concrete are important during its use. These important characteristics, namely:

\section{a. Concrete compression test}

The strength of this concrete is expressed by the maximum load it can carry because the increasing strength of the concrete increases its other properties.

\section{b. Tensile test}

There are two kinds of concrete tensile test, including the Nazile tensile test and the direct tensile test, where the Nazile tensile test is to determine the split tensile strength value in the concrete, while the direct tensile test is to determine the value of the concrete tensile strength directly. Durability

Apart from the strength of the concrete, another thing that needs to be considered is the ability of concrete to last during the construction life. In order to produce durable concrete, efforts must be made to select suitable mix materials with good ratios in order to produce a homogeneous and easily compacted concrete.

\section{b. Age and compressive strength of concrete}

The compressive strength of concrete is determined when the concrete reaches 28 days of age. "The strength of concrete will increase rapidly (linearly) until the age of 28 days, but after that the increase is not too significant" (Prawito, 2010). To estimate the compressive strength of each specimen against concrete that is 28 days old, it can be seen in table 1 below:

Table 1 Conversion Factors for 28 Days Concrete Compressive Strength

\begin{tabular}{|l|c|c|c|c|c|c|c|}
\hline $\begin{array}{l}\text { Age of } \\
\text { concrete } \\
\text { (days) }\end{array}$ & 3 & 7 & 14 & 21 & 28 & 90 & 365 \\
\hline $\begin{array}{l}\text { Ordinary } \\
\text { Portland } \\
\text { cement }\end{array}$ & 0.40 & 0.65 & 0.88 & 0.95 & 1.00 & 1.20 & 1.35 \\
\hline $\begin{array}{l}\text { Portland } \\
\text { cement } \\
\text { with } \\
\text { high } \\
\text { initial } \\
\text { strength }\end{array}$ & 0.55 & 0.75 & 0.90 & 0.95 & 1,00 & 1.15 & 1.20 \\
\hline
\end{tabular}

\section{- Fly Ash}

The use of coal as an energy source to replace $\mathrm{BBM}$, on the one hand is very profitable, but on the other hand it can cause problems. The main problem with using coal is coal ash which is a byproduct of burning coal. The amount of use of coal will produce about $2-10 \%$ coal ash. At present, the management of coal ash waste is limited to landfilling in the factory area (ash disposal). Coal ash is part of coal combustion residue in the form of fine amorphous particles. The ash is an inorganic material that is formed from changes in mineral matter due to the combustion process. The process of burning coal in a steam generator unit (boiler) will form two types of ash, namely fly ash, and bottom ash. The composition of coal ash consists of 10$20 \%$ base ash and $80-90 \%$ in the form of fly ash. Fly ash is captured by the electric precipitator before being discharged into the air through the chimney. Many studies have been conducted to examine the effect of added materials on improving the quality of concrete. (Damayanti and Rochman, 2006). 
- Carbide Waste

Carbide waste is B3 waste originating from the acetylene gas production process. The carbide waste comes from the reaction between water and carbide in an acetylene gas-making reactor. Based on the Attachment to Government Regulation Number 101 of 2014 concerning Management of Hazardous and Toxic Waste, carbide waste is included in the list of B3 waste from a specific source with the waste code B356-1 with the chronic hazard category. Carbide waste has a chemical composition of $60 \%$ Calcium $(\mathrm{CaO}), 1.48 \%$ $\mathrm{SiO} 2,0.09 \% \mathrm{Fe} 2 \mathrm{O} 3,9.07 \% \mathrm{Al} 2 \mathrm{O} 3$, in the same study it is known that the main constituent of cement is calcium derived from limestone. The high calcium content makes this carbide waste have physical properties similar to calcium hydroxide in that the largest chemical compound is $\mathrm{Ca}(\mathrm{OH}) 2$, the binding capacity to water is quite high, has a grainy texture, has a distinctive odor, and grain diameter. -grains relatively larger than clay grains. The addition of carbide waste is an effort to increase the calcium element required in the occurrence of a pozzolanic reaction when mixed with $\mathrm{SiO} 2$ in the carbide waste. The pozzolanic reaction is a reaction between calcium, silica, or aluminate with water to form a hard and stiff mass which is almost the same as the hydration process in Portland Cement (Rajiman, 2015).

\section{RESEARCH METHODS}

The scope of research

This research was conducted in the city of Palembang, with the source material for cement baturaja, coarse aggregate from the Lahat area, fine aggregate from the Tanjung Raja area, carbide waste from the residue from welding carbide in the Cinde Palembang market, and fly ash is the residue of coal combustion.

\section{RESEARCH METHODS}

Material Quality Testing

Bulk and SSD specific gravity testing and fine aggregate absorption

The fine aggregate to be used will be mixed with other materials, so it is necessary to know the specific gravity value, this is important because it will be used when calculating the concrete mix design.

- Coarse Aggregate Sieve Analysis Test Results

The test results are as shown in Table 2 and Figure 1.
Table 2 Test Results of Coarse Aggregate Sieve Analysis.

\begin{tabular}{|c|c|c|c|c|}
\hline $\begin{array}{c}\text { Sieve } \\
\text { Size } \\
(\mathrm{mm})\end{array}$ & \multicolumn{2}{|c|}{$\begin{array}{c}\text { Retained Aggregate } \\
\text { Weight }\end{array}$} & \multicolumn{2}{c|}{ Cumulative Percent } \\
\cline { 2 - 5 } & Gram & $\%$ & Retained & Pass \\
\hline 38 & 0 & 0 & 0 & 100,00 \\
\hline 19 & 295 & 24,583 & 24,583 & 75,42 \\
\hline 9,5 & 521 & 43,417 & 68,000 & 32,00 \\
\hline 4,80 & 215,2 & 17,933 & 85,933 & 14,07 \\
\hline 2,4 & 107,3 & 8,942 & 94,875 & 5,13 \\
\hline 1,2 & 29,5 & 2,458 & 97,333 & 2,67 \\
\hline 0,6 & 30,1 & 2,508 & 99,842 & 0,16 \\
\hline 0,3 & 0,3 & 0,025 & 99,867 & 0,13 \\
\hline 0,15 & 0,3 & 0,025 & 99,892 & 0,11 \\
\hline 0,075 & 0,2 & 0,017 & 99,908 & 0,09 \\
\hline PAN & 1,1 & 0,092 & & \\
\hline Total & 1200 & 100 & 770,233 & \\
\hline
\end{tabular}

Grain Fineness Modulus =\% Cumulative Retained / $100=$ Modulus of fineness $=770.23 / 100=7,702$.

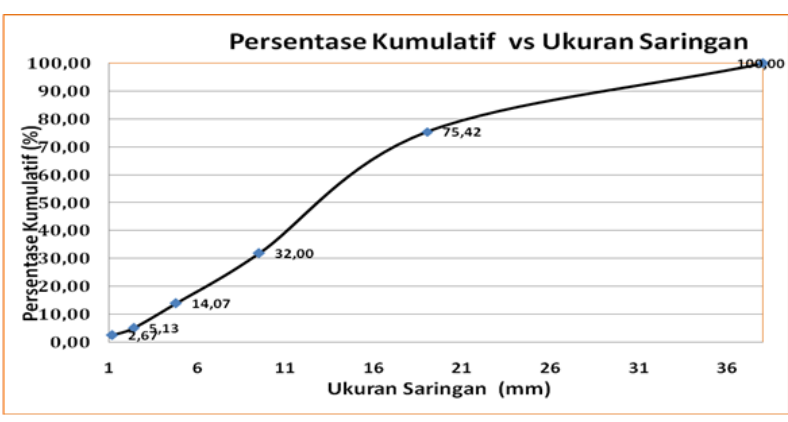

Figure 1 Coarse Aggregate Gradation

- Fine Aggregate Sieve Analysis Test Results

The results of the sieve analysis for fine aggregate are as shown in Table 3 and illustrated in Figure 2.

Table 3 Test Results for Fine Aggregate Sieve Analysis

\begin{tabular}{|c|c|c|c|c|}
\hline $\begin{array}{c}\text { Sieve } \\
\text { Size } \\
(\mathrm{mm})\end{array}$ & \multicolumn{2}{|c|}{$\begin{array}{c}\text { Retained Aggregate } \\
\text { Weight }\end{array}$} & \multicolumn{2}{c|}{ Cumulative Percent } \\
\cline { 2 - 5 } & Gram & $\%$ & Retained & Pass \\
\hline 9,5 & 0 & 0 & 0 & 100 \\
\hline 4,80 & 7,5 & 0,75 & 0,75 & 99,25 \\
\hline 2,40 & 17,5 & 1,75 & 2,5 & 97,5 \\
\hline 1,20 & 264,5 & 26,45 & 28,95 & 71,05 \\
\hline 0,60 & 552,2 & 55,22 & 84,17 & 15,83 \\
\hline 0,30 & 122,7 & 12,27 & 96,44 & 3,56 \\
\hline 0,15 & 8,2 & 0,82 & 97,26 & 2,74 \\
\hline 0,075 & 27,4 & 2,74 & & \\
\hline PAN & 1000 & 100 & & \\
\hline
\end{tabular}

Grain Fineness Modulus =\% Cumulative Retained $/$ $100=309.32 / 100=3.09$ 


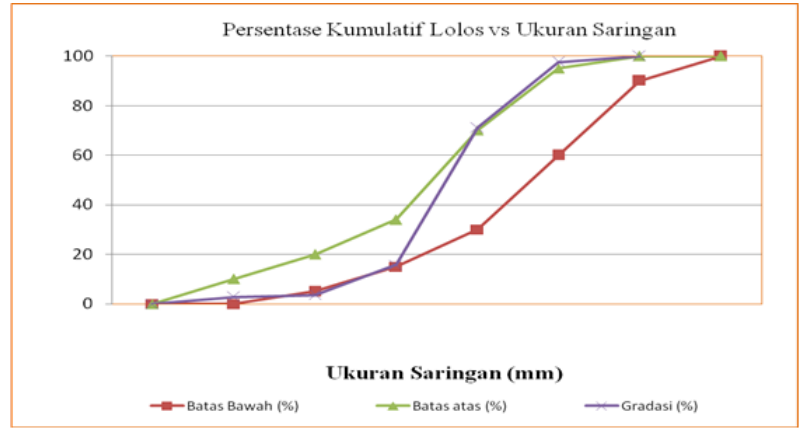

Figure 2 Gradation of Fine Aggregate

The results of the fine aggregate sieve analysis show that the gradation of fine aggregate enters zone 1 , which means that the sand used is a bit course compared to ideal grains.

- Bulk and SSD specific gravity and fine aggregate absorption testing

The fine aggregate to be used will be mixed with other materials, so it is necessary to know the specific gravity value, this is important because it will be used when calculating the design of the mixture so that it can be seen how much fine aggregate is needed for other concrete constituents.

The results of the specific gravity and absorption of fine aggregates are shown in Table 4.

Table 4 Results of Density Testing and Fine Aggregate Absorption

\begin{tabular}{|l|l|c|}
\hline Code & Description & Weight (grams) \\
\hline A & $\begin{array}{l}\text { The weight } \\
\text { of the } \\
\text { saturated dry } \\
\text { specimen }\end{array}$ & 500 \\
\hline B & $\begin{array}{l}\text { Weight of } \\
\text { oven dry } \\
\text { specimen }\end{array}$ & \\
\hline C & $\begin{array}{l}\text { Pycnometer } \\
\text { weight }+ \\
\text { water }\end{array}$ & 475 \\
\hline D & $\begin{array}{l}\text { Pycnometer }+ \text { water }+ \\
\text { specimen weight }\end{array}$ & 1267 \\
\hline Bj Bulk = B / C+A-D) & 1552,4 \\
\hline $\begin{array}{l}\text { Bj SSD }=\text { A / C + A - } \\
\text { D) }\end{array}$ & 2,210 \\
\hline $\begin{array}{l}\text { Absorption = (A-B) / B } * \\
100 \%\end{array}$ & $5,260 \%$ \\
\hline
\end{tabular}

- Testing of Bulk and SSD specific gravity and coarse aggregate absorption
Coarse aggregate density ranges from 2.0-2.6, the greater the density of the aggregate, the better the resulting concrete. The results of specific gravity and coarse aggregate absorption are shown in Table 5

Table 5 Density Testing Results and Coarse Aggregate Absorption

\begin{tabular}{|l|l|c|}
\hline Code & \multicolumn{1}{|c|}{ Description } & $\begin{array}{c}\text { Weight } \\
\text { (grams) }\end{array}$ \\
\hline A & $\begin{array}{l}\text { The weight of the } \\
\text { saturated dry specimen }\end{array}$ & 500,00 \\
\hline B & $\begin{array}{l}\text { Weight of oven dry } \\
\text { specimen }\end{array}$ & 485,00 \\
\hline C & $\begin{array}{l}\text { Pycnometer weight + } \\
\text { water }\end{array}$ & $\begin{array}{c}1302,4 \\
0\end{array}$ \\
\hline D & $\begin{array}{l}\text { Pycnometer + water + specimen } \\
\text { weight }\end{array}$ & 1594,8 \\
\hline Bj Bulk = B / (C+A-D) & 2,336 \\
\hline Bj SSD = A / (C + A - D) & 2,408 \\
\hline \multicolumn{2}{|l|}{ Absorption = (A-B) / B * 100\% } & 3,092 \\
$\%$
\end{tabular}

- Aggregate Hardness Testing

This examination is intended to determine the value of coarse aggregate hardness against loading. The results of the Aggregate Hardness test are shown in Table 6.

Table 6 Test of Aggregate Strength Against Pressure

\begin{tabular}{|c|c|c|c|}
\hline Item Testing & & $\begin{array}{l}\text { Weigh } \\
\mathrm{t} 1(\mathrm{gr})\end{array}$ & $\begin{array}{l}\text { Weigh } \\
\text { t } 2 \text { (gr) }\end{array}$ \\
\hline $\begin{array}{l}\text { Container weight }+ \\
\text { the sample passed } \\
\# 12,5 \mathrm{~mm} \text { dan }\end{array}$ & $y$ weight of & & \\
\hline rained \# $10 \mathrm{~mm}(\mathrm{gr})$ & ) & 3115,4 & 3390 \\
\hline Container & (W2 & & \\
\hline Weight (gr) & ) & 217,4 & 408 \\
\hline $\begin{array}{l}\text { Dry Weight of } \\
\text { Sample (gr) }\end{array}$ & $\begin{array}{l}\mathrm{Wa}= \\
(\mathrm{W} 1- \\
\mathrm{W} 2)\end{array}$ & 2898 & 2982 \\
\hline $\begin{array}{l}\text { Weight After } \\
\text { Impact and Pass } \\
\# 2,36 \mathrm{~mm} \text { (gr) } \\
\text { (W4) }\end{array}$ & & 31,2 & 36,38 \\
\hline $\begin{array}{l}\text { Aggregates } \\
\text { Crushing Value } \\
(\%)\end{array}$ & $\begin{array}{r}(\mathrm{Wb} \\
\quad) \\
\end{array}$ & 1,08 & 1,22 \\
\hline Average & $(\%)$ & \multicolumn{2}{|c|}{1,150} \\
\hline
\end{tabular}

\section{- Aggregate Wear Testing}

The aggregate wear test aims to determine the resistance of coarse aggregates to wear using a Los Angeles machine. The wear is expressed by the ratio 
between the weight of the wear material through sieve no. 12 to the original weight, as shown in Table 7.

Table 7. Aggregate Wear Tests with Los Angeles Machinesv(SNI 03-2417-1991)

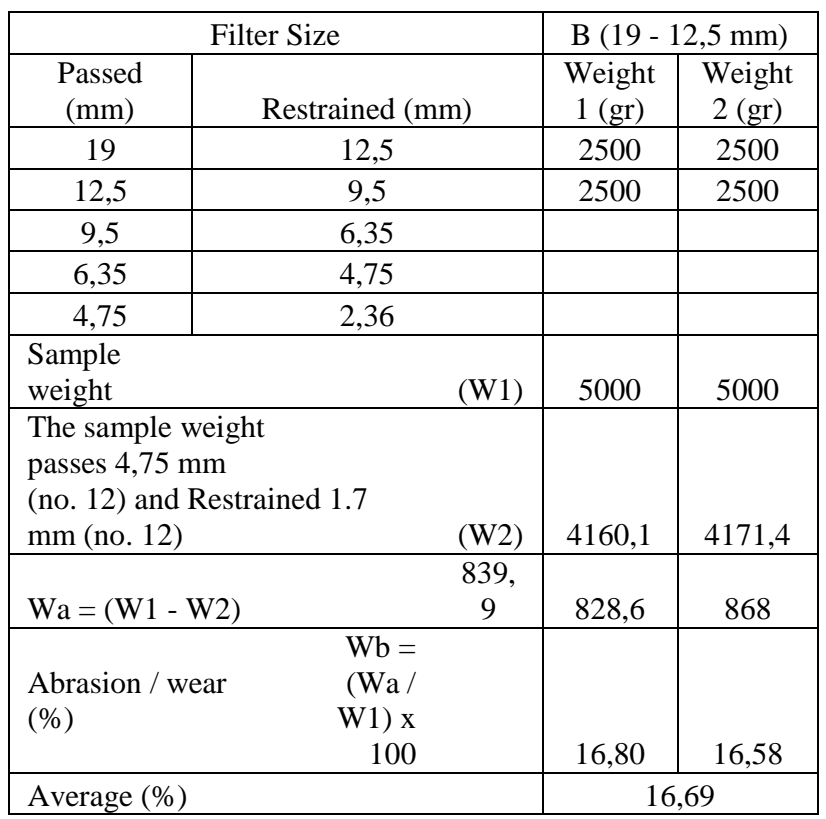

Specifications

(\%): 40

\section{- Portland Cement Density Testing}

The results of the cement density test are as shown in Table 8.

Table 8 Cement Density Test (SNI 15-2531-1991)

\begin{tabular}{|l|c|}
\hline \multicolumn{1}{|c|}{ Testing Item } & Weight 1 (gr) \\
\hline Sample weight & 64,00 \\
\hline $\begin{array}{l}\text { First reading on the bottle } \\
\text { scale (V1) }\end{array}$ & 0,92 \\
\hline $\begin{array}{l}\text { Second reading on the bottle scale } \\
\text { (V2) }\end{array}$ & 21,52 \\
\hline Transfer of Liquid Contents (V2-V1) & 20,10 \\
\hline $\begin{array}{l}\text { Water content weight } \\
\text { temperature 4 }{ }^{\circ} \mathrm{C}\end{array}$ & 1,00 \\
\hline $\begin{array}{l}\text { Specific Gravity }=\mathrm{W} 1 /(\mathrm{V} 2-\mathrm{V} 1)^{*} \\
\text { d }\end{array}$ & 3,18 \\
\hline Specifications: $3.0-3.20$ &
\end{tabular}

Table 9 Fly Ash Density Test

\begin{tabular}{|l|c|}
\hline \multicolumn{1}{|c|}{ Testing Item } & Weight 1 (gr) \\
\hline Sample weight & 50,00 \\
\hline First reading on the bottle scale (V1) & 0,70 \\
\hline $\begin{array}{l}\text { Second reading on the bottle scale } \\
\text { (V2) }\end{array}$ & 21,40 \\
\hline Transfer of Liquid Contents (V2-V1) & 20,70 \\
\hline
\end{tabular}

\begin{tabular}{|c|c|}
\hline (d) & 1,00 \\
\hline $\begin{array}{l}\text { Specific Gravity = W1 } \\
/(\mathrm{V} 2-\mathrm{V} 1) * \mathrm{~d}\end{array}$ & 2,42 \\
\hline Testing Item & Weight 1 (gr) \\
\hline Sample weight & 50,00 \\
\hline First reading on the bottle scale (V1) & 0,70 \\
\hline $\begin{array}{l}\text { Second reading on the bottle scale } \\
\text { (V2) }\end{array}$ & 21,40 \\
\hline Transfer of Liquid Contents (V2-V1) & 20,70 \\
\hline (d) & 1,00 \\
\hline $\begin{array}{l}\text { Specific Gravity }=\mathrm{W} 1 \\
/(\mathrm{V} 2-\mathrm{V} 1) * \mathrm{~d}\end{array}$ & 2,42 \\
\hline Specific Gravity $=\mathrm{W} 1 /(\mathrm{V} 2-\mathrm{V} 1) * \mathrm{~d}$ & 1,92 \\
\hline
\end{tabular}

- Comparison of concrete compressive strength without using fly ash and carbide waste to the compressive strength of normal concrete, as shown in Figure 3

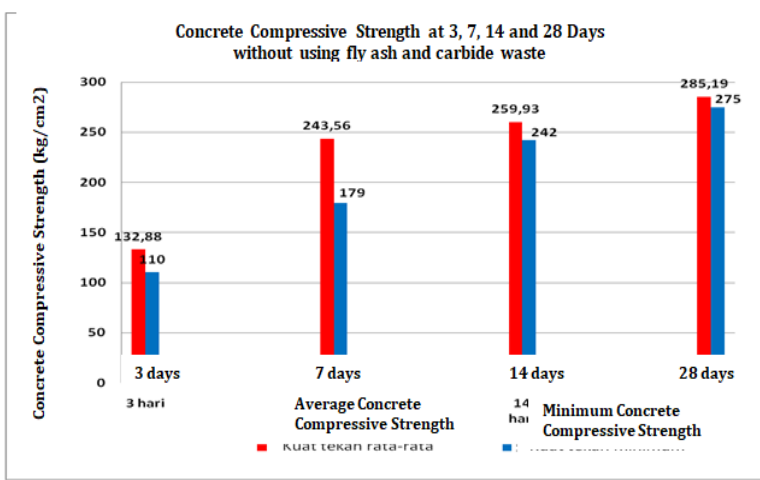

Figure 3. Concrete Compressive Strength without using fly ash and carbide waste

From the results of concrete compressive strength test, at the age of $3,7,14$ and 28 days are 132.88 $\mathrm{kg} / \mathrm{cm} 2, \quad 243.56 \mathrm{~kg} / \mathrm{cm} 2, \quad 259.93 \mathrm{~kg} / \mathrm{cm} 2, \quad 285.19$ $\mathrm{kg} / \mathrm{cm} 2$. These results of the concrete compressive strength test above have met the planned compressive strength of the concrete, which is $275 \mathrm{~kg} / \mathrm{cm} 2$ at the age of 28 days.

- Comparison of Concrete Compressive Strength using fly ash and carbide waste $20 \% 20 \%$ (FA + LK) vs $80 \%$ $\mathrm{PC}$, as shown in Figure 4 


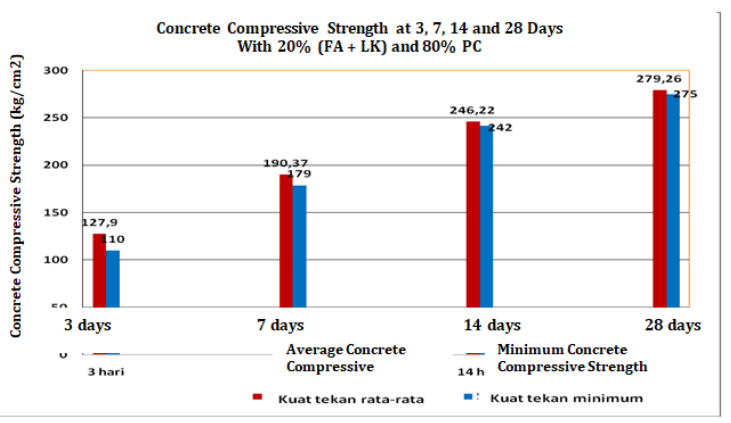

Figure 4. Concrete Compressive Strength With 20\% $(\mathrm{FA}+\mathrm{LK})$ and $80 \% \mathrm{PC}$

Based on the results of concrete compressive strength test, the compressive strength for the material $20 \%(\mathrm{FA}+\mathrm{LK})$ and $80 \% \mathrm{PC}$ at the age of 3 days is $127.29 \mathrm{~kg} / \mathrm{cm} 2,7$ days of age is $190.37 \mathrm{~kg} / \mathrm{cm} 2$, age 14 day of $246.22 \mathrm{~kg} / \mathrm{cm} 2$ and 28 days of age of 279.26 $\mathrm{kg} / \mathrm{cm} 2$. These results of the concrete compressive strength test have met the planned concrete compressive strength which is $275 \mathrm{~kg} / \mathrm{cm} 2$ at the age of 28 days.

- Comparison of Concrete Compressive Strength using fly ash and carbide waste $40 \%$ (FA + LK) vs $60 \%$ PC, as shown in Figure 5.

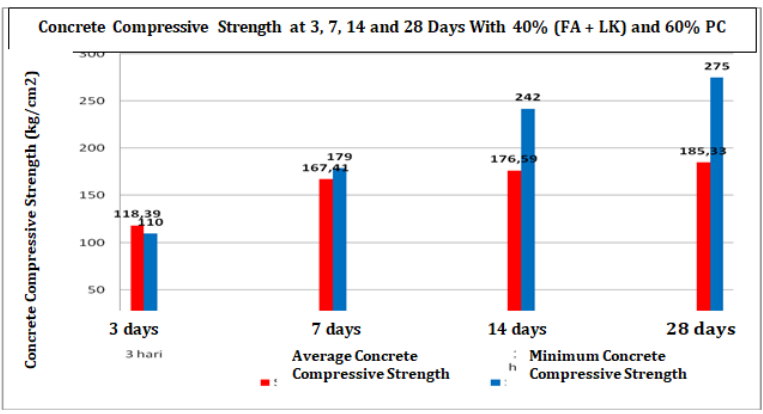

Figure 5. Concrete Compressive Strength With $40 \%$ $(\mathrm{FA}+\mathrm{LK})$ and $60 \% \mathrm{PC}$

Based on the results of concrete compressive strength test, the compressive strength for the material $40 \%(\mathrm{FA}+\mathrm{LK})$ and $60 \% \mathrm{PC}$ at the age of 3 days is $118.39 \mathrm{~kg} / \mathrm{cm} 2$, at the age of 7 days is $167.41 \mathrm{~kg} / \mathrm{cm} 2$, 14 days $176.69 \mathrm{~kg} / \mathrm{cm} 2$ and at the age of 28 days $185.33 \mathrm{~kg} / \mathrm{cm} 2$. These results have met the planned concrete compressive strength which is $275 \mathrm{~kg} / \mathrm{cm} 2$ at the age of 28 days.

- Comparison of Concrete Compressive Strength using fly ash and carbide waste $60 \%$ (FA + LK) vs $40 \%$ PC, as shown in Figure 6.

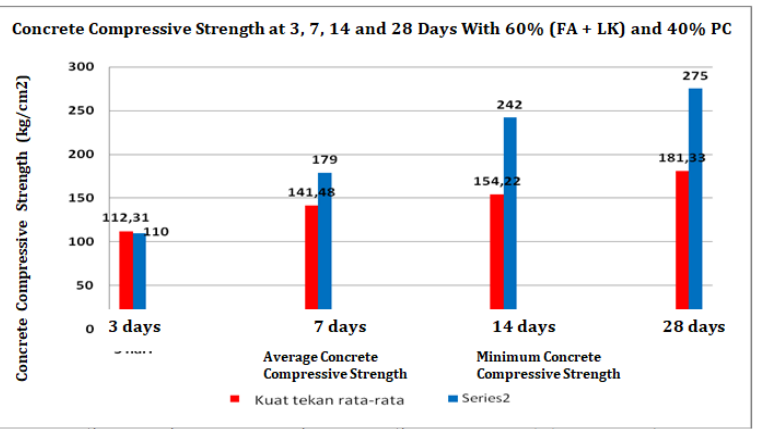

Figure 6. Concrete Compressive Strength With 60\% $(\mathrm{FA}+\mathrm{LK})$ and $40 \% \mathrm{PC}$

From the results of concrete compressive strength test, the compressive strength for the material is $60 \%$ $(\mathrm{FA}+\mathrm{LK})$ and $40 \% \mathrm{PC}$, at the age of 3 days is 112.41 $\mathrm{kg} / \mathrm{cm} 2,7$ days is $141.48 \mathrm{~kg} / \mathrm{cm} 2$, age 14 days is 154.22 $\mathrm{kg} / \mathrm{cm} 2$ and 28 days old is $181.33 \mathrm{~kg} / \mathrm{cm} 2$. These results of the concrete compressive strength test above did not meet the planned concrete compressive strength, which is $275 \mathrm{~kg} / \mathrm{cm} 2$ at the age of 28 days.

- Comparison of Concrete Compressive Strength using fly ash and carbide waste $80 \%$ (FA + LK) vs $20 \%$ PC, as shown in Figure 7

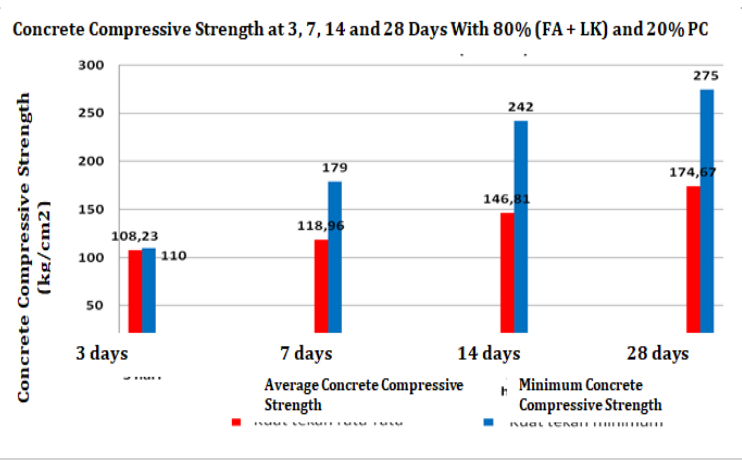

Figure 7. Comparison of the compressive strength With $80 \%(\mathrm{FA}+\mathrm{LK})$ and $20 \% \mathrm{PC}$

From the results of concrete compressive strength test, the compressive strength for the material is $80 \%$ (FA + LK) and $20 \% \mathrm{PC}$, at the age of 3 days is $108.23 \mathrm{~kg} / \mathrm{cm} 2$, age 7 days is $118.96 \mathrm{~kg} / \mathrm{cm} 2$, age 14 days is 146.81 $\mathrm{kg} / \mathrm{cm} 2$ and 28 days is $174.67 \mathrm{~kg} / \mathrm{cm} 2$. The results of the concrete compressive strength test above did not meet the planned concrete compressive strength, which is 275 $\mathrm{kg} / \mathrm{cm} 2$ at the age of 28 days

\section{CONCLUSION}

The conclusions that can be drawn from the results of this study are as follows:

1. Comparison of the percentage of fly ash and carbide waste with a cement percentage of 0.00 / 100; 20/80; 40/60; 60/40; and 80/20\%. 
2. The results of concrete compressive strength test without fly ash and carbide waste, respectively, obtained the compressive strength of concrete at the ages of 3,7 , 14 and 28 days, namely $132.88 \mathrm{~kg} / \mathrm{cm} 2,243.56 \mathrm{~kg} / \mathrm{cm} 2$, $259.93 \mathrm{~kg} / \mathrm{cm} 2,285.19 \mathrm{~kg} / \mathrm{cm} 2$. These results of the concrete compressive strength test above have met the planned compressive strength of the concrete, which is $275 \mathrm{~kg} / \mathrm{cm} 2$ at the age of 28 days.

3. Comparison of the compressive strength of concrete with $20 \%(\mathrm{FA}+\mathrm{LK})$ and $80 \% \mathrm{PC}$ at the ages $3,7,14$ and 28 days, the compressive strength at 3 days is $127.29 \mathrm{~kg} / \mathrm{cm} 2$, age 7 days amounted to $190.37 \mathrm{~kg} / \mathrm{cm} 2$, 14 days of age $246.22 \mathrm{~kg} / \mathrm{cm} 2$ and 28 days of age $279.26 \mathrm{~kg} \mathrm{/} \mathrm{cm} 2$. These results of the concrete compressive strength test above have met the planned compressive strength of the concrete, which is 275 $\mathrm{kg} / \mathrm{cm} 2$ at the age of 28 days.

4. Comparison of the compressive strength of concrete with 40\% (FA + LK) and 60\% PC; 60\% (FA + LK) and $40 \% \mathrm{PC} ; 80 \%(\mathrm{FA}+\mathrm{LK})$ and $20 \% \mathrm{PC}$ at the ages of 3 , 7, 14 and 28 days did not meet the planned compressive strength of the concrete, namely $275 \mathrm{~kg} / \mathrm{cm} 2$ at the age of 28 days.

5. Concrete mixture using 20\% (FA + LK) and 80\% PC is the best concrete mixture, and the compressive strength of concrete is $279.26 \mathrm{~kg} / \mathrm{cm} 2$.

6. The more percentage of fly ash and carbide waste used into the concrete mixture, the more concrete compressive strength will decrease..

\section{REFERENCES}

[1] American Society for Testing and Materials (ASTM) 2002. Annual Book of ASTM Standards, Printed in Easton, Md. USA.

[2] American Association of State Highway and Transportation Official (AASHTO) 1998. Part I: Methods of Sampling and Testing, Washington, D.C.

[3] Alfian H.U., Marthin D.J.S., Reky S. W. (2014). Effect of Utilization of Fly Ash from PLTU North Sulawesi as Partial Substitution of Cement on Concrete Compressive Strength, Journal of Civil Static Vol 2 No 7, November 2014 ISSN 23376732 Manado.

[3] Alizar, (2010). "Construction materials technology teaching materials majoring in civil engineering

[4] Mercu Buana University”, Center for UMB teaching materials development, Jakarta.
[4] Antono, A. (1995). Civil Engineering Construction Materials, Publisher Atma Jaya University, Jakarta.

[5] Asward, N.H. (2012) The Use of Welding Carbide Waste and Rice Husk Ash as Cement Substitution Materials in Paving Blocks. Metropilar Volume 11 Number 3.

[6] Damayanti, I., and Rochman, A. (2006). "Overview of the Addition of Microsilica and Fly Ash to the Compressive Strength of High-Quality Concrete", Journal of Eco Engineering UMS.

[7] Ministry of Public Works (2011). Concrete Compressive Strength Testing Method, SNI 1974: 2011, Bandung.

[8] Department of Public Works (2011), Methods of making and treating specimens concrete in the laboratory, SNI 2493: 2011, Bandung.

[9] Ministry of Public Works (2012). Procedure for making mixed plans for normal concrete, SNI 7656: 2012, Bandung.

[10] Kh, Sunggono, (1994). Civil Engineering Book, NOVA Publisher, Bandung.

[11] Mulyono, Tri (2005). Concrete Technology, Andi Offset Publisher, Yogyakarta.

[12] Murdock L.J, and Brook K.M. (1999). Concrete Materials and Practices, Publisher: Erlangga, Jakarta

[13] Prawito, Eri, (2010), "Comparison analysis of density and compressive strength of concrete between lightweight concrete and normal concrete with K-200 concrete quality, University of North Sumatra, Medan.

[14] Pujianto, A. (2010). "High Quality Concrete with Addition of Superplasticizer and Fly Ash", UMY Semesta Teknika Scientific Journal, Vol. 13, No. 2, pp 171-180.

[15] Rajiman. (2015). The Effect of Addition of Carbide Waste and Natural Aggregate Material (Feldspart) on the Physical Properties of Concrete. Footprint Vol. 4 No. 2, 118-124.

[16] SNI M - 091989 - F Density Testing and Absorption of Coarse Aggregates.

[17] SNI M - 101989 - F Density Testing and Absorption of Fine Aggregates.

[18] SNI M - 021990 - F Aggregate Wear Testing with Los Angeles Abrasion 